\title{
Psychologie učení: Teoretické a výzkumné poznatky pro edukační praxi
}

\section{Jana Černá}

PRŮCHA, Jan. Psychologie učení: teoretické a výzkumné poznatky pro edukační praxi. Praha: Grada, 2020. Psyché (Grada). ISBN 978-80-271-2853-2.

DOI: $10.5507 /$ epd.2021.005

Autorem monografie Psychologie učení: teoretické a výzkumné poznatky pro edukační je prof. PhDr. Jan Průcha, DrSc., vysokoškolský pedagog, čelní představitel české moderní pedagogiky, zakladatel České asociace pedagogického výzkumu, který působí i v mezinárodních vědeckých organizacích a redakčních radách odborných časopisů. Jeho přístup je pozoruhodný tím, že se nenechává svazovat tradičními teoriemi pedagogiky, jež mají svým normativním př́stupem snahu stanovovat, jaká by výchova měla být, nýbrž přichází s explanačním přístupem, tedy hledá a objasňuje příčiny a souvislosti. Publikace má 268 stran a je členěna do 12 tematicky na sebe navazujících kapitol, za nimiž následují prílohy, literatura a rejstřík. Orientaci v textu usnadňuje zvýrazněné písmo, tabulky a tzv. rámce (je jich celkem 17), které jsou vždy konkretizací a praktickým uchopením teoreticky popisovaného. Kapitoly, vyjma kapitol 5, 6 a 7, začínají úvodním prologem a jsou následovně členěné do 2 až 4 podkapitol. $V$ této své nejnovější publikaci autor představuje a podrobně komentuje fenomén lidského učení, přičemž popisuje, jak se postupně vyvíjel v historickém kontextu psychologie a pedagogiky. Zabývá se především zahraničními empirickými výzkumy zaměřenými na to, jakou roli 
hrají v lidském učení inteligence a motivace, ale také komunikace. Dále kniha věnuje pozornost tomu, jak jsou procesy učení realizovány, v jakých prostředích se učení odehrává, a pojednává také o učení v kontextu autoregulace. Následně se dozvídáme, jak se lidé učí z textu a jakým způsobem si osvojují svůj první, tedy mateřský jazyk. Závěrečná kapitola obsahuje přehled nejvýznamnějších výzkumných center, vědeckých asociací, publikací a časopisů, jež se zabývají psychologií učení. Následující príloha stručně shrnuje hlavní myšlenky publikace Encyclopedia of the Sciences of Learning a upozorňuje na skutečnost, že není v reálných možnostech jednoho autora postihnout fenomén učení v celé jeho širíi. Tato monografie nicméně významně zaplňuje informační mezeru na poli současné české psychologie a pedagogiky v oblasti zkoumání lidského učení a upozorňuje na zahraniční vědecké př́istupy, metody a výzkumné poznatky především v zemích jako jsou USA, Německo a Velké Británie. Současně je však nutné upozornit na to, že nezahrnuje oblast, která je pro současné zkoumání učení velmi aktuální, tedy učení prostřednictvím nových technologií a umělé inteligence, napríklad strojové učení (machine learning) a učení s pomocí robotů (robot-assisted learning). Profesoru Průchovi se velmi dobře podařilo vybalancovat prezentaci teorie nutné pro pochopení konkrétní problematiky a prezentaci výzkumů a/nebo aplikovaných metod dosud v českém prostředí nepř́liš známých. Vysoce oceňuji jeho detailní analýzu a porovnávání zahraničních a českých výzkumů, kde nespouští ze zřetele fakt, že edukace má být založena na důkazech (evidence-based education). $V$ duchu této teorie si také klade otázky, na které si současně odpovídá, čímž čtenář získává nový a komplexnější pohled na celou tuto problematiku optikou českého renomovaného odborníka. Kniha je určena všem, kteří se věnují tématu učení, tedy učitelům, instruktorům a lektorům, stejně jako vědeckým pracovníkům v pedagogických a psychologických oborech, protože výrazně usnadňuje orientaci v současných zahraničních trendech psychologie učení a velmi dopodrobna prezentuje a analyzuje výzkumná šetření a studie. V neposlední řadě může dobře posloužit studentům orientovaným na pedagogiku a psychologii, a také celé široké veřejnosti, protože je psána velmi srozumitelně, přičemž současně poskytuje racionálně podložené závěry a mnoho podnětných otázek i komentárưu, což vše poukazuje na vysokou odbornost a fundovanost autora.

\section{Kontakt:}

Mgr. Jana Černá

Ústav cizích jazyků, Pedagogická fakulta Univerzity Palackého v Olomouci

Žižkovo nám. 5, 77140 Olomouc, Česká republika

e-mail: jana.cerna@upol.cz 